\title{
Genetic parameters and prediction of breeding values in Castanopsis hystrix A.DC. for growth and form traits
}

\author{
By F. Q. ZHANG ${ }^{1)}$, B. XU ${ }^{1)}$, H. X. YANG ${ }^{1)}$, W. H. ZHANG ${ }^{1)}$, \\ B. Z. ZHU ${ }^{1)}$, Y. X. WANG ${ }^{1)}$, H. Q. LIAO ${ }^{1)}$ and W. PAN ${ }^{1), *)}$
}

(Received 24 $4^{\text {th }}$ September 2014)

\begin{abstract}
Castanopsis hystrix A.DC. is one of the most important and multipurpose tree species native to China. 157 open-pollinated families collected from 11 provenances in Guangdong, Guangxi, and Fujian province were used to estimate genetic parameters for height $(\mathrm{H})$, diameter at breast height $(\mathrm{DBH})$, ground diameter (GD), and crown width $(\mathrm{CW})$ for each province and combined three provinces at ages from 3 to 9 years. The variance component was small and non-significant among provenances but was highly significant among families within provenances for $\mathrm{H}, \mathrm{DBH}, \mathrm{GD}$, and CW. Heritability estimates were significant except for a few traits from Fujian's provenances. Heritability ranged from 0.20 to 0.57 for $\mathrm{H}, 0.19$ to 0.38 for $\mathrm{DBH}, 0.21$ to 0.55 for GD, and 0.09 to 0.39 for CW. Heritability estimates for $\mathrm{H}$ and $\mathrm{DBH}$ decreased with increased age for each province and combined three provinces. Significantly high genetic correlations were observed for ageage and trait-trait correlations, indicating that genetic performance at one trait was well correlated with another trait. In total, 22 families and 60 individuals were selected for backward and forward selection based on breeding values.
\end{abstract}

Keywords: Castanopsis hystrix; additive variance; individual heritability; genetic correlation; breeding values.

\section{Introduction}

Forest tree species typically have long rotations and long breeding cycles, indicating that tree improvement programs need to be well organized and structured at the start to maximize genetic gain for short and long-term

\footnotetext{
1) Guangdong Provincial Key Laboratory of Bio-control for the Forest Disease and Pest, Guangdong Academy of Forestry, Guangzhou, 510520, P. R. China.

*) Corresponding author: WEN PAN. Tel/Fax: 86-2087033558. E-mail: panwen@sinogaf.cn
}

(WHITE et al., 2007). Castanopsis hystrix A.DC. is one of the most important and multifunctional tree species native to China because of its good growth characteristics, desirable wood properties, and broad utilization range (HUANG et al., 2012). It is found naturally in southern China in Guangxi, Guangdong, Hainan, and Yunnan provinces between $21^{\circ} \mathrm{N}$ and $35^{\circ} \mathrm{N}$ and $109^{\circ} \mathrm{E}$ and $117^{\circ} \mathrm{E}$. Castanopsis hystrix can be planted as pure stand or mixed with other species such as conifers and firs. Over the past three decades, C. hystrix resources in China have expanded as an important tree species of structural- and appearance-grade wood products with the combined plantation area in Guangdong and Guangxi has reached approximately 5000 ha (ZHU et al., 2005). A comprehensive provenance-progeny tests was initiated in the 1990s with the aim of further selective breeding (ZHU et al., 2005; HUANG et al., 2012).

Breeding of $C$. hystrix for commercially important traits is a relatively recent development for increasing the productivity of newly established plantations. The program is following the principle of two successful long-term tree breeding programs: radiata and loblolly pine. Genetic improvement of radiata pine [Pinus radiata $\mathrm{D}$. Don] was initiated in the 1950s in Australia with the initial plus tree selection for open-pollinated (OP) family testing. The first two generations of radiata pine selective breeding focused on growth and form traits; the average rotation length for radiata pine plantations decreased from about 40-55 years to about 30-35 years (LI and Wu, 2005; Wu et al., 2007, 2008). The third generation of radiata pine breeding in Australia focused on genetic variation in wood quality traits (MATHESON et al., 2008; GAPARE et al., 2009). Genetic improvement of loblolly pine was also initiated in the $1950 \mathrm{~s}$, and the North Carolina State University Cooperative Tree Improvement Program (NCSU) with initial provenance and progeny trials and achieved genetic gains up to $30 \%$ using third-generation 
selectively bred loblolly pine when compared to unimproved genetic material (McKEAND et al., 2001, 2003).

Genetic variance among individuals is typically partitioned into non additive and additive components. Non additive variance can be further divided into epistatic variance due to interactions of genes at two or more loci and dominance variance caused by intra-locus gene interactions (FALCONER and MACKAY, 1996). However, genetic parameter estimates based on OP seed orchards during forest tree breeding have largely focused on additive genetic models in the form of family or individual tree models. In C. hystrix, no reports are available on the use of OP progenies for describing the structure of the genetic variance. In addition, no estimates have been published of the breeding values of C. hystrix, although predictions of breeding values for other forest tree species are a standard prectices (XIE et al., 2007; IsIK et al., 2008; IWATA et al., 2011; HARDNER et al., 2012; DENIS and Bouvet, 2013). At this time, studies on the genetics of $C$. hystrix have focused on height $(\mathrm{H})$, diameter at breast height $(\mathrm{DBH})$, ground diameter (GD), and crown width (CW); these related traits are the most important for wood production at initial breeding effort (GREAVES et al., 1997).

The objectives of this study were to (1) compare genetic variation at the additive levels in $\mathrm{DBH}, \mathrm{H}, \mathrm{GD}$, and $\mathrm{CW}$ among the three provinces and combined three provinces; (2) estimate heritability for growth and form traits at different ages using the family model for each province and combined three provinces; (3) estimate additive genetic correlations between the traits; and (4) estimate family and individual-tree breeding values based on combined three provinces to select elite trees for grafting into seed orchards.

\section{Materials and Methods}

\section{Genetic material}

Genetic materials were collected from three provinces as:

Guangdong provenance: Sixty-four OP families were collected from three provenances of Xinyi, Gaozhou, and Luhe in October and November 2001. Guangxi provenance: OP seeds from 51 plus trees were collected from five provenances of Pubei, Bobai, Rongxian, Pingxiang, and Donglan in October and November 2000.

Fujian provenance: OP seeds from 42 plus trees were collected from three provenances of Zhangzhou, Jinshan, and Huaan in October and November 2001. Details on seed source collection information for the 11 provenances at the three provinces are provided in Table 1.

\section{Provenance-progeny trial and measurement}

The 11 provenances from the three provinces were planted in 2002-2003 at Longyandong Forest Farm in Guanzhou City, Guangdong Province, China $\left(23^{\circ} 10^{\prime}-23^{\circ} 18^{\prime} \mathrm{N}, 113^{\circ} 21^{\prime}-\right.$ $\left.113^{\circ} 27^{\prime} \mathrm{E}\right)$. The site has an arenaceous shale lateritic red soil ( $\mathrm{pH} 4.75-5.20)$ and receives an average annual rainfall of $1,760 \mathrm{~mm}$ (Table 1). Location of natural Castanopsis hystrix provenances in China is described in Fig. 1. 3-5 trees

Table 1. - Details of Castanopsis hystrix A.DC. provenance location.

\begin{tabular}{|c|c|c|c|c|c|c|c|c|c|c|}
\hline $\begin{array}{l}\text { Prov, } \\
\text { Conde }\end{array}$ & Prov. & $\begin{array}{c}\text { No. of } \\
\text { fanilics }\end{array}$ & $\begin{array}{c}\text { Spacing } \\
(\mathrm{m})\end{array}$ & $\begin{array}{l}\text { Location, } \\
\text { Country }\end{array}$ & I ongitude ( $F$ ) & latitude $(\mathrm{N})$ & $\begin{array}{c}\text { Altitude } \\
(\mathrm{m})\end{array}$ & Temperature & $\begin{array}{c}\text { Rainfall } \\
\text { (mm/year) }\end{array}$ & Survival $(\%)$ \\
\hline 1 & GiD21 & 11 & $2 \times 3$ & xinyi, China & $110400^{\circ}-11140^{\circ}$ & $2216-2242$ & 300 & 22.3 & 1700.0 & \\
\hline 3 & GD 23 & 33 & $2 \times 3$ & Luhe, China & $11524^{\prime}-11519^{\circ}$ & $2306-2832^{\prime}$ & 407 & 21.8 & 2100.0 & \\
\hline 4 & $G \times 11$ & 12 & $2 \times 3$ & Pubei, China & $10914^{\prime}-10913^{\prime}$ & $2214^{\prime}-2241^{\prime}$ & 230 & 21.4 & 1787.3 & \\
\hline 6 & $\mathrm{G} \times 13$ & 9 & $2 \times 3$ & Rongxian, China & $11015^{\prime}-11053^{\circ}$ & $2228^{\prime}-2308^{\prime}$ & 214 & 21.3 & 16600.2 & 82.1 \\
\hline 7 & $6 \times 15$ & 4 & $2 \times 3$ & Pingxiang, China & $10641-10659$ & $2151-2216$ & 300 & 21.3 & 1376.5 & \\
\hline 8 & $6 \times 17$ & 12 & $2 \times 3$ & Donglan, Chiла & $10705^{\prime}-10743^{\prime}$ & $2410^{\prime}-2430^{\prime}$ & 394 & 20.1 & 1577.1 & \\
\hline 9 & IJ J3] & 26 & $2 \times 3$ & Jinshan.China & $11733^{\prime}-11734^{\prime}$ & $2457^{\prime}-2458^{\prime}$ & 140 & 20.8 & 1631.5 & \\
\hline 10 & $\mathrm{FJ} 32$ & 4 & $2 \times 3$ & Gaoche, China & $117^{\prime} 16^{\prime}-11744^{\prime}$ & $2430^{\prime}-2512$ & 200 & 20.6 & 1870.1 & 74.6 \\
\hline
\end{tabular}




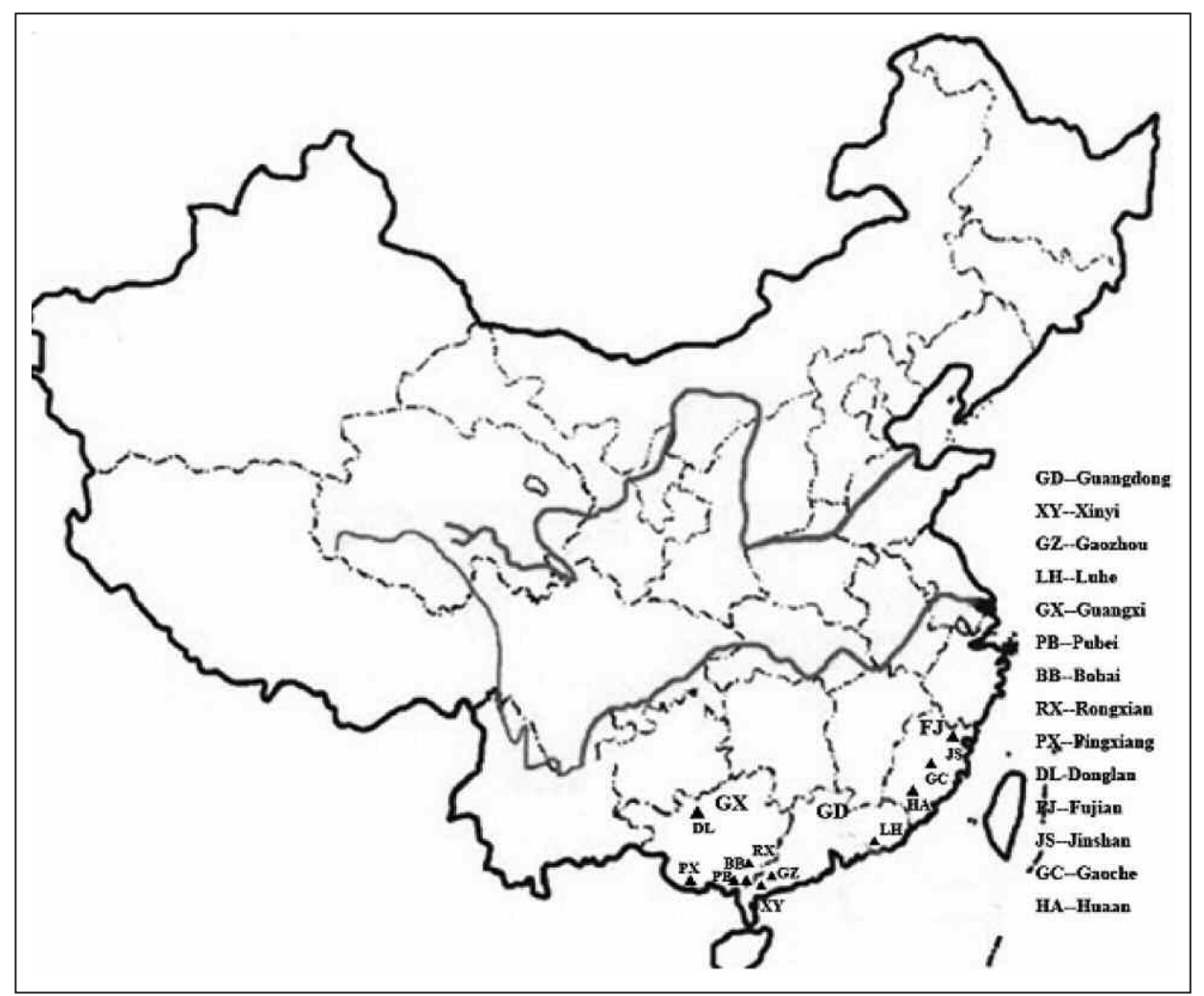

Figure 1. - Location of natural Castanopsis hystrix provenances in China: Xinyi, Gaozhou, Luhe, Pubei, Bobai, Rongxian, Pingxiang, Donglan, Jinshan, Gaoche, and Huaan.

for family plot Seedlings were planted using $2 \times 3 \mathrm{~m}$ spacing, with five, six, and seven replications for populations from Guangdong, Guangxi and Fujian, respectively, using randomized complete block designs. $\mathrm{H}$ and $\mathrm{DBH}$ were measured during 2005-2010 for all families of the three provinces (e.g. age 3 to 9 based on populations and traits see detail from Table 3). DBH was measured at $1.3 \mathrm{~m}$ above the ground. GD of the three provinces was investigated and CW was the average of east-west and north-south directions in 2005, which were important for wood production.

\section{Statistical analyses}

Preliminary family mixed model analyses were performed using the statistical software ASReml (GILMOUR et al., 2009) to calculate different variance components. Provenance effects were not significant and were dropped in the final analyses. The data were analyzed using univariate and multivariate family mixed models. ASReml fits the general mixed model, and was used for combined and separate analyses for three provinces.

$$
\mathrm{y}=\mathbf{X} b+\mathbf{Z} u+e,
$$

where $y$ is an $n \times 1$ vector of observations in the trial. For combined province analysis, the $\mathrm{b}$ is a vector of fixed effects (including the trial mean, replication, province and year effect, respectively), $\mathbf{X}$ is an $\mathrm{n} \times \mathrm{w}$ design matrix that mapped the observations onto the fixed effects, $\mathbf{Z}$ is an $\mathrm{n} \times \mathrm{m}$ matrix that mapped the observations onto the genotype effects (including provenance, family within provenance), $\mathrm{u}$ is a $\mathrm{p} \times 1$ vector of random effects (including familywithin-provenance, province by replication, and family-within-provenance by replication interaction), and $\mathrm{e}$ is an $\mathrm{n} \times 1$ vector of unknown residuals. For each individual province analyses, the $b$ is a vector of fixed effects (including trial mean, replication), and $u$ is vector of random effects (including family across provenance, and family by replication).

Individual-tree narrow-sense heritability was estimated for each province and combined three provinces, as follows:

$$
h^{2}=\frac{4 \times \sigma_{\text {Fam }}^{2}}{\sigma_{\text {Fam }}^{2}+\sigma_{\text {Fam Rep }}^{2}+\sigma_{a}^{2}},
$$


where $\sigma^{2} F a m$ is the family variance component within provenance, $\sigma^{2}$ Fam.Rep is the interaction variance family by replication, and $\sigma_{e}^{2}$ is the residual variance component.

To compare the levels of additive genetic variance in each trait independent of their means, we estimated the genetic coefficient of variation $\left(\mathrm{CV}_{\mathrm{A}}\right)($ CORNELIUS, 1994)

$$
\mathrm{CV}_{\mathrm{A}}=\frac{\widehat{\sigma}_{\overline{\mathrm{A}}}}{x} \times 100 \% \text {, }
$$

where $\mathrm{CV}_{\mathrm{A}}$ is the coefficient of additive genetic variation, $\sigma_{\mathrm{A}}$ is the square root of the additive genetic variance for a trait, and $x$ is the trait phenotypic mean in the trial. The $\mathrm{CV}_{\mathrm{A}}$ represents the genetic variance relative to the mean of the trait of interest: the higher the $\mathrm{CV}_{\mathrm{A}}$ for a trait, the higher its relative variation.

Additive genetic correlation estimates between traits $\mathrm{X}$ and $\mathrm{Y}$ were obtained from the estimated additive covariance and variance components within provenance as

$$
r_{A}=\frac{\operatorname{cov}_{X Y}}{\sqrt{\sigma_{X}^{2} \times \sigma_{Y}^{2}}},
$$

where $\mathrm{COV}_{X Y}$ is the additive genetic covariance component between trait $\mathrm{X}$ and trait $\mathrm{Y}, \sigma^{2} X$ is the additive genetic variance for trait $\mathrm{X}$ withinprovennace at each province, and $\sigma^{2}{ }_{Y}$ is additive genetic variance for trait $\mathrm{Y}$ within-provennaces at each province. The additive genetic correlation estimates for combined three provinces between two traits were computed similar to equation (4).

The efficiency of early selection relative to mature age per generation was calculated as

$$
E=\frac{100 \times i_{j} h_{j} r_{g}}{i_{m} h_{m}}
$$

where $i_{j}$ and $i_{m}$ are the selection intensity in the juvenile trait (dbh at age 5 and 6 ) and mature trait (dbh at age 8 and 9), respectively, assum- ing that $i_{j}=i_{m}$, and $h_{j}$ and $h_{m}$ are the square root of heritability estimates for the juvenile age and the mature age, respectively; and $r_{g}$ is the additive genetic correlation of juvenile and mature traits.

\section{Results and Discussion}

Provenance survival, growth, and form

Survival of Guangdong and Fujian provenances at age 8 years and Guangxi provenance at age 9 years were $89.6 \%, 74.6 \%$, and $82.1 \%$, respectively (Table 1). Generally, the best growth rate was observed in Guangxi provenances, but $\mathrm{CW}$ and GD were similar among the three provinces (Table 2). DBH at age 5 or 6 years at Guangdong and Guangxi provinces ranged from $3.88 \mathrm{~cm}$ to $8.21 \mathrm{~cm}$ and at age 8 or 9 years ranged from 11.19 to $13.02 \mathrm{~cm}$. The differences between Guangdong and Guangxi was getting smaller from earlier age (5 or 6 ) to age 8 or 9 for DBH, but almost unchanged for HT.

\section{Effect on variance and individual heritability}

Variance components for all the traits at each province are shown in Table 3 . The family variance $\left(\mathrm{V}_{\mathrm{Fam}}\right)$ estimated for growth and form traits were significant at all ages for Guangdong and Guangxi populations, while only HT, $\mathrm{CW}$ and GD at age 3 , and $\mathrm{DBH}$ at age 8 were significant for Fujian. The family by replication interaction was not significant for all traits except for DG4 of Guangxi province at age 4 . The genetic coefficient of variation (CV) was between $2.9 \%$ to $7.9 \%$ and was similar for most traits at different ages. The additive and residual error variances for $\mathrm{H}, \mathrm{DBH}$ and $\mathrm{CW}$ except for HT3 (4) increased with increased age, and we did not observe significant provenance variance components for combined three provinces.

Generally, heritabilities for most traits were low to moderate, and significant heritabilities were observed for all traits for each province

Table 2. - Means for growth and form traits of Castanopsis hystrix A.DC. by each province; means are followed by their standard deviations.

$\begin{array}{lllllll}\text { Prov. } & \text { DBH5 }(6)(\mathrm{cm})^{\mathrm{a}} & \mathrm{DBH} 8(9)(\mathrm{cm}) & \mathrm{HT} 5(6)(\mathrm{m}) & \mathrm{HT} 8(9)(\mathrm{ml}) & \mathrm{CW} 5(6)(\mathrm{m}) & \text { GD3(4)(cm) } \\ \text { Guangdong } & 3.88 \pm 1.81 & 11.19 \pm 3.25 & 4.64 \pm 1.51 & 10.16 \pm 3.52 & 2.16 \pm 0.67 & 2.10 \pm 0.70 \\ \text { Guangxi } & 8.21 \pm 3.05 & 13.02 \pm 3.12 & 7.32 \pm 2.28 & 14.55 \pm 4.51 & 3.87 \pm 1.26 & 5.73 \pm 1.78 \\ \text { Fujian } & 3.60 \pm 1.73 & 9.35 \pm 3.45 & 3.83 \pm 1.42 & 7.08 \pm 2.18 & 2.21 \pm 0.77 & 2.19 \pm 0.69\end{array}$

a Measurement age are varied among different province population. 
Table 3. - Variance components for family across provenance, family $\times$ replication interaction, residual errors, heritability, and genetic coefficient of variation (CV) for different traits in each province.

\begin{tabular}{|c|c|c|c|c|c|c|}
\hline Prov. & Truit & $V_{\text {T:Im! }}$ & $V_{\text {Eam }} \cdot \operatorname{Rep}$ & $\mathrm{V}_{\mathrm{I}}$ & Ueritability & CV $(\%)$ \\
\hline \multirow{9}{*}{ Guangdong } & HT3 & $0.06 * 2 *$ & 0.01 & 0.37 & $0.55 \pm 0.10$ & 3.6 \\
\hline & HT5 & 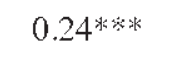 & 0.03 & 2.07 & $0.41 \pm 0.09$ & 3.3 \\
\hline & HT8 & $0.46^{213 * 4}$ & $\mathrm{NA}$ & 8.27 & $0.21 \pm 0.06$ & 7.9 \\
\hline & DВH3 & $0.02^{* * * *}$ & 0.002 & 0.19 & $0.38 \pm 0.09$ & 5.0 \\
\hline & DBH5 & $0.27^{* \infty}$ & 0.001 & 3.09 & $0.32 \pm 0.08$ & 4.8 \\
\hline & DBH8 & $0.46^{4}$ & VA & 9.47 & $0.19 \pm 0.05$ & 2.9 \\
\hline & $\mathrm{CW3}$ & $84.93^{* \cdots}$ & 13.35 & 776.21 & $0.39 \pm 0.09$ & 3.4 \\
\hline & CW5 & 136.67 水米 & 16.64 & 4320.61 & $0.12 \pm 0.04$ & 4.0 \\
\hline & GD3 & $0.07^{* * *}$ & 0.003 & 0.44 & $0.55 \pm 0.12$ & 3.4 \\
\hline \multirow{9}{*}{ Guangxi } & HT4 & $0.17^{\text {米: }}$ & 0.04 & 1.57 & $0.38 \pm 0.09$ & 3.2 \\
\hline & IIT6 & $0.25^{* * *}$ & $N A$ & 4.76 & $0.20 \pm 0.07$ & 3.2 \\
\hline & HTS & $1.07^{135 * *}$ & $\mathrm{NA}$ & 17.4 & $0.23 \pm 0.08$ & 4.2 \\
\hline & $\mathrm{DBH} 4$ & $0.10 * *$ & 0.01 & 1.67 & $0.22 \pm 0.08$ & 3.4 \\
\hline & DBH6 & 0.42 水为 & $\mathrm{VA}$ & 8.39 & $0.19 \pm 0.07$ & 3.8 \\
\hline & DBH9 & $0.43 * *$ & $\mathrm{NA}$ & 7.38 & $0.22 \pm 0.08$ & 2.9 \\
\hline & CW4 & $102.90^{*}$ & 164.86 & 4338.52 & $0.09 \pm 0.05$ & 3.5 \\
\hline & CW6 & 612.85 的水 & $\mathrm{NA}$ & 13267.9 & $0.18 \pm 0.06$ & 3.8 \\
\hline & GD4 & $0.16 *$ & $0.17^{* *}$ & 2.74 & $0.21 \pm 0.07$ & 3.2 \\
\hline \multirow{7}{*}{ Fujian } & HT3 & 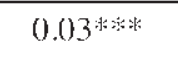 & NA & 0.3 & $0.36 \pm 0.11$ & 3.6 \\
\hline & HTS & 0.034 & $\mathrm{NA}$ & 4.6 & $0.03 \pm 0.09$ & 5.2 \\
\hline & DBH3 & 0.007 & 0.01 & 0.16 & $0.16 \pm 0.15$ & 5.3 \\
\hline & DBH5 & 0.014 & 0.02 & 3.04 & $0.02 \pm 0.07$ & 4.9 \\
\hline & DBH8 & $0.60^{*}$ & YA & 10.68 & $0.21 \pm 0.11$ & 3.7 \\
\hline & CW3 & $88.40^{* \ldots 13}$ & $\mathrm{NA}$ & 829.17 & $0.39 \pm 0.14$ & 3.9 \\
\hline & GD3 & $0.06^{\mathrm{k}-25}$ & $\mathrm{NA}$ & 0.44 & $0.48 \pm 0.13$ & 3.3 \\
\hline
\end{tabular}

${ }^{*}, \mathrm{P}<0.05 ;{ }^{* *}, \mathrm{P}<0.01 ;{ }^{* * * *}, \mathrm{P}<0.001$.

and combined three provinces except CW4 for Guangxi population and HT8, DBH3, and DBH5 for Fujian population (Table 3). Heritability estimates for $\mathrm{HT}$ and $\mathrm{DBH}$ decreased over time for Guandong population, from 0.55 to 0.21 for $\mathrm{HT}$, and from 0.38 to 0.19 for $\mathrm{DBH}$. Heritability estimates for Guangxi and Fujian population have no obvious age trend. Standard errors for heritabilities in Fujian were larger probably because of the small sample size. Heritability estimates for $\mathrm{HT}, \mathrm{DBH}$ and $\mathrm{CW}$ decreased over time for combined three provinces, from 0.54 to 0.21 for HT, from 0.37 to 0.18 for $\mathrm{DBH}$, and from 0.22 to 0.13 for $\mathrm{CW}$, respectively (Table 4).

Among the three provinces, Fujian had the lowerest additive genetic variance for growth and form traits than the other two provinces.
There was only one reported heritabilities for $\mathrm{DBH}$ and HT (0.63 and 0.71 at age 3 , respectively) for C. hystrix. (ZHU et al., 2005). The estimated heritability of $\mathrm{HT}$ and $\mathrm{DBH}$ at age 8 or 9 years in $C$. hystrix was similar to estimates in many other genetic studies such as radiata pine (JAYAWICKRAMA, 2001; WU and MATHESON, 2002; LI and WU, 2005; Wu et al., 2007), loblolly pine (GWAZE et al., 2001; ERICSSON and FRIES, 2004; Fries and ERICSSon, 2006, 2009; Fries, 2012), and eucalyptus (LOPEz et al., 2002; PoTTs et al., 2004; FREEMAN et al., 2007).

\section{Effect of province and combined three provinces on genetic correlation}

The genetic correlations for age-age and traittrait were estimated for populations from 
Table 4. - Variance components for province by replication, family-within-province, and family-within-province by replication interaction, residual errors, heritability and stand error for different traits combined three provinces analysis.

\begin{tabular}{|c|c|c|c|c|c|}
\hline Trait & 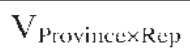 & $V_{\text {HitIII }}$ & $V_{\text {fillmXRejs }}$ & $V_{\mathrm{t}}$ & Heritability \\
\hline $\mathrm{HT} 3(4) \mathrm{a}$ & 0.01 & $0.12^{\text {* } x^{*} \text { * }}$ & $\mathrm{NA}$ & 0.79 水必 & $0.54 \pm 0.07$ \\
\hline $\operatorname{HT} 5(6)$ & 0.1 & $0.20 * * ; *$ & $0.22^{2}$ & $2.80^{\text {kn }=k}$ & $0.24 \pm 0.04$ \\
\hline HI8(9) & 0.27 & $0.59 * *$ * * * & $0.95 \%$ 水水 & $9.54^{*}$ *k & $0.21 \pm 0.04$ \\
\hline DBH3(4) & 0.01 & $0.09 * * * *$ & 0.01 & $0.82 * k *$ & $0.37 \pm 0.06$ \\
\hline DBH5(6) & $0.13^{*}$ & $0.28 * * * *$ & $0.30^{* * * *}$ & $4.69 * \cdots$ & $0.21 \pm 0.04$ \\
\hline DBH8(9) & $0.40^{*}$ & $0.39 * * * *$ & $0.59 \div * \cdots$ & $7.62^{* * 1}$ & $0.18 \pm 0.04$ \\
\hline CW3(4) & $\mathrm{NA}$ & $0.06^{* k}$ & $\mathrm{NA}$ & $0.20^{\text {* * : }: 4: 3}$ & $0.22 \pm 0.04$ \\
\hline CW5(6) & $0.12 *$ & $0.03^{* 2}$ & $0.05^{\text {sk:k }}$ & $0.73^{\text {*a } * k}$ & $0.13 \pm 0.03$ \\
\hline $\operatorname{GD3}(4)$ & $\mathrm{NA}$ & $0.15^{\text {粈将: }}$ & 0.03 & $1.26^{* 1 *}$ & $0.41 \pm 0.06$ \\
\hline
\end{tabular}

${ }^{a}$ Measurement age are varied among different province population.

Table 5. - Genetic correlations of the same traits (height and diameter at breast height) at different ages for Guangdong, Guangxi province and combined three provinces.

\begin{tabular}{ccccccc}
\hline Provenance & Trait & DBH3(4) & DBH5(6) & Trait & HT3(4) & HT5(6) \\
\hline \multirow{2}{*}{ Guangdong } & DBH5 & $0.99 \pm 0.03$ & & H'5 & $0.96 \pm 0.02$ & \\
& DBH8 & $0.81 \pm 0.10$ & $0.91 \pm 0.05$ & HT8 & $0.76 \pm 0.09$ & $0.78 \pm 0.08$ \\
\hline \multirow{2}{*}{ Guangxi } & DBI6 & $0.95 \pm 0.05$ & & ITT6 & $0.99 \pm 0.02$ & \\
& DBH9 & $0.56 \pm 0.21$ & $0.86 \pm 0.09$ & HT9 & $0.85 \pm 0.08$ & $0.88 \pm 0.07$ \\
\hline Combined & DBH5 $(6)$ & $0.99 \pm 0.06$ & & HT5(6) & $0.99 \pm 0.04$ & \\
provinces & DBH8(9) & $0.68 \pm 0.11$ & $0.99 \pm 0.09$ & HT8 $(9)$ & $0.92 \pm 0.05$ & $0.97 \pm 0.05$ \\
\hline
\end{tabular}

${ }^{a}$ Measurement age are varied among different province population.

Table 6. - Genetic correlations among different traits for Guangdong, Guangxi provinces and combined three provinces.

\begin{tabular}{|c|c|c|c|c|c|c|c|}
\hline \multirow[b]{2}{*}{ Prov. } & \multirow[b]{2}{*}{ Trait } & \multicolumn{3}{|c|}{ Height } & \multicolumn{2}{|c|}{ Crown } & \multirow{2}{*}{$\begin{array}{l}\text { Ground } \\
\text { diameler } \\
\text { GD3(4) }\end{array}$} \\
\hline & & $\operatorname{HT} 3(4)^{\mathrm{a}}$ & HT5(6) & HT8(9) & $\mathrm{CW} 3(4)$ & CW5(6) & \\
\hline \multirow{6}{*}{ Guangdong } & $\mathrm{DBH} 3$ & $0.98 \pm 0.0 \mathrm{~L}$ & $0.90 \pm 0.04$ & $0.74 \pm 0.11$ & $0.92 \pm 0.04$ & $0.98 \pm 0.09$ & $0.96 \pm 0.01$ \\
\hline & DBH5 & $0.97 \pm 0.02$ & $0.97 \pm 0.01$ & $0.88 \pm 0.05$ & $0.97 \pm 0.03$ & $0.97 \pm 0.04$ & $0.97 \pm 0.02$ \\
\hline & DBH8 & $0.84 \pm 0.07$ & $0.87 \pm 0.06$ & $0.99 \pm 0.04$ & $0.81 \pm 0.09$ & $0.93 \pm 0.08$ & $0.81 \pm 0.08$ \\
\hline & CW3 & $0.94 \pm 0.02$ & $0.91 \pm 0.04$ & $0.77 \pm 0.09$ & - & - & $0.97 \pm 0.01$ \\
\hline & CW5 & $0.99 \pm 0.06$ & $0.89 \pm 0.06$ & $0.93 \pm 0.08$ & - & - & $0.98 \pm 0.06$ \\
\hline & GD3 & $0.94 \pm 0.02$ & $0.86 \pm 0.04$ & $0.82 \pm 0.07$ & $0.96 \pm 0.01$ & $0.98 \pm 0.06$ & - \\
\hline \multirow{6}{*}{ Guangxi } & DBH4 & $0.98 \pm 0.01$ & $0.96 \pm 0.06$ & $0.87 \pm 0.10$ & $0.90 \pm 0.10$ & $0.95 \pm 0.08$ & $0.99 \pm 0.01$ \\
\hline & DBH6 & $0.92 \pm(1.05$ & $0.93 \pm 0.04$ & $0.99 \pm 0.02$ & $0.85 \pm 0.15$ & $0.97 \pm 0.03$ & $0.92 \pm 0.06$ \\
\hline & DBH9 & $0.75 \pm 0.13$ & $0.82 \pm 0.10$ & $0.93 \pm 0.05$ & $0.81 \pm 0.16$ & $0.91 \pm 0.07$ & $0.81 \pm 0.12$ \\
\hline & CW4 & $0.82 \pm 0.11$ & $0.73 \pm 0.18$ & $0.81 \pm 0.16$ & - & - & $0.91 \pm 0.08$ \\
\hline & CW6 & $0.94 \pm 0.06$ & $0.97 \pm 0.04$ & $0.95 \pm 0.04$ & - & - & $0.99 \pm 0.06$ \\
\hline & GD4 & $0.97 \pm 0.02$ & $0.95 \pm 0.06$ & $0.89 \pm 0.08$ & $0.91 \pm 0.08$ & & - \\
\hline \multirow{6}{*}{ Combined provinces } & $\mathrm{DBH} 3(4)$ & $0.98 \pm 0.01$ & $0.99 \pm 0.39$ & $0.94 \pm 0.07$ & $0.91 \pm 0.03$ & $0.99 \pm 0.09$ & $0.97 \pm 0.01$ \\
\hline & DBH5(6) & $0.99 \pm 0.03$ & $0.95 \pm 0.01$ & $0.99 \pm 0.08$ & $0.99 \pm 0.05$ & $0.95 \pm 0.02$ & $0.99 \pm 0.04$ \\
\hline & DBH $8(9)$ & $0.83 \pm 0.06$ & $0.96 \pm 0.06$ & $0.89 \pm 0.04$ & $0.92 \pm 0.06$ & $0.99 \pm 0.07$ & $0.85 \pm 0.06$ \\
\hline & $\mathrm{CW} 3(4)$ & $0.83 \pm 0.06$ & $.99 \pm 0.05$ & $0.97 \pm 0.06$ & - & - & $0.94 \pm 0.02$ \\
\hline & CW5 $(6)$ & $0.99 \pm 0.04$ & $0.91 \pm 0.03$ & $0.99 \pm 0.08$ & - & - & $0.99 \pm 0.08$ \\
\hline & GD3(4) & $0.96 \pm 0.01$ & $0.99 \pm 0.04$ & $0.98 \pm 0.05$ & $0.94 \pm 0.02$ & $0.99 \pm 0.08$ & - \\
\hline
\end{tabular}

a Measurement age are varied among different province population. 
Guangdong, Guangxi provinces and combined three provinces (Tables 5 and 6 ). Age-age correlations were all above 0.70 except correlation between DBH8 (9) and DBH3 (4) in Guangxi population and combined three provinces. In Guangdong population, the age-age genetic correlations for DBH and HT were significant and averaged 0.90 and 0.83 , respectively (Table 5). In Guangxi population, the age-age genetic correlations for DBH and HT were significant and averaged 0.79 and 0.91 , respectively. In combined three provinces, the age-age genetic correlations for $\mathrm{DBH}$ and $\mathrm{HT}$ were significant and averaged 0.89 and 0.96 , respectively, indicating that HT genetic correlations were larger than $\mathrm{DBH}$. The trait-trait genetic correlations for $\mathrm{HT}, \mathrm{DBH}, \mathrm{CW}$, and GD were generally significant and high, ranged from 0.73 to 0.99 for both Guandong, Guangxi populations and combined three provinces. The standard errors for genetic correlations for all traits were less than 0.20 (Table 6).
Family and individual selections based on breeding values

The top six best provenances were FJ31, GX11, GX15, GD22, GD23 and GX13 according to the provenance best linear unbiased predictions (BLUP) effects based on combined three provinces, indicating that provenance selections were low in Fujian and high in Guangxi and Guangdong (Table 7). Some changes occurred in family ranking based on an analysis of each province and combined three provinces: $72.7 \%$ were the same families compared to the two analyses (data not shown for each province). Breeding values for families 64, 51, and 42 were predicted for DBH at age 8 and 9 years for combined three provinces. At a selection rate of $15 \%$, families 9,5 , and 8 were selected for Guangdong, Guangxi and Fujian, respectively, and the genetic gains were $1.06 \mathrm{~cm}, 0.77 \mathrm{~cm}$, and $0.74 \mathrm{~cm}$, respectively. From these results, 22 families were used to establish first-generation clone orchards using only the highest-rank-

Table 7. - Growth performances and predicted breeding values of selected families and all provenances for combined three provinces at age 8 and 9 years.

\begin{tabular}{|c|c|c|c|c|c|}
\hline \multirow{2}{*}{ Provenance } & \multirow{2}{*}{$\frac{\text { Breeding value }}{\mathrm{DB} \mathrm{B} 8(9)^{\mathrm{a}}}$} & \multirow{2}{*}{$\begin{array}{l}\text { Family } \\
\text { Code }\end{array}$} & \multicolumn{2}{|c|}{ Growth performance } & \multirow{2}{*}{$\frac{\text { Breeding value }}{\text { DBH } 8(9)}$} \\
\hline & & & HT $8(9)$ & DBH8(9) & \\
\hline FJ31 & 0.654 & 224 & 11.50 & 13.48 & 1.417 \\
\hline GX11 & 0.268 & 226 & 11.44 & 12.89 & 1.322 \\
\hline GX 15 & 0.241 & 250 & 11.97 & 12.79 & 1.310 \\
\hline $\mathrm{GD} 22$ & 0.193 & 259 & 10.91 & 12.46 & 1.133 \\
\hline $\mathrm{GD} 23$ & 0.076 & 8 & 16.82 & 14.06 & 1.129 \\
\hline $\mathrm{G} \times 13$ & 0.036 & 236 & 11.79 & 12.73 & 1.026 \\
\hline FJ33 & -0.115 & 219 & 11.27 & 12.44 & 1.013 \\
\hline GX17 & -0.199 & 314 & 8.29 & 11.79 & 0.999 \\
\hline GD21 & -0.269 & 302 & 7.86 & 11.12 & 0.968 \\
\hline $\mathrm{GX} 12$ & -0.346 & 225 & 11.27 & 12.30 & 0.902 \\
\hline \multirow[t]{13}{*}{ FJ32 } & -0.539 & 49 & 16.52 & 13.75 & 0.804 \\
\hline & & 304 & 7.11 & 10.48 & 0.782 \\
\hline & & 214 & 11.64 & 12.39 & 0.760 \\
\hline & & 10 & 15.89 & 15.26 & 0.715 \\
\hline & & 332 & 7.81 & 10.41 & 0.706 \\
\hline & & 231 & 11.21 & 12.12 & 0.677 \\
\hline & & 305 & 7.92 & 10.52 & 0.645 \\
\hline & & 331 & 7.41 & 10.37 & 0.637 \\
\hline & & 41 & 18.73 & 17.80 & 0.597 \\
\hline & & 43 & 15.59 & 13.36 & 0.595 \\
\hline & & 324 & 7.29 & 10.41 & 0.590 \\
\hline & & 306 & 7.29 & 10.73 & 0.584 \\
\hline & & Mean & 11.25 & 12.44 & \\
\hline
\end{tabular}

${ }^{a}$ Measurement age are varied among different province population. 
ing backward selections, and these families originated from the gene pools that were grafted.

Breeding values were predicted for $\mathrm{DBH}$ in 4,283 OP progeny within combined three provenances, which were achieved using a mixed linear model with pedigree information unbiased by selection; 60 individuals from the highest ranked 46 families from 11 provenances were selected for second seed orchard establishment (Table 8). Our study is the first to provide breeding values for $C$. hystrix. The breeding values of family and individual for growth and form traits are additive genetic values for studied traits; therefore, selection based on breeding values can enhance the average value of studied traits in the progeny and increase the frequency of progeny with improved characteristics.
Efficiency of early selection and implications for improvement of growth and form traits

Early selection is practiced in tree breeding because long-rotation time for each generation. For the Guangdong province, the heritability for $\mathrm{DBH}$ at ages 5 and 8 was significantly different (Table 3), and the genetic correlation was estimated 0.91 between age 5 and 8 years for DBH. Such high genetic correlation indicated that selection for DBH using age 5 data would be as effective as selection at age 8 years. For the Guangxi province and combined three provinces, the heritability for $\mathrm{DBH}$ at ages 6 and 9 years was nearly identical (Table 3 and Table 4), and the genetic correlation for $\mathrm{DBH}$ at two age years was 0.86 and 0.99 . The early selection at age 6 years on DBH for Guangxi and combined three provinces appeared to yield

Table 8. - Growth performances and predicted breeding values of selected individuals for combined three provinces at age 8 and 9 years.

\begin{tabular}{|c|c|c|c|c|c|c|c|c|c|c|c|}
\hline \multirow{2}{*}{$\begin{array}{l}\text { lree } \\
\text { Code }\end{array}$} & \multirow[t]{2}{*}{ Provenance } & \multirow{2}{*}{$\begin{array}{l}\text { I'amily } \\
\text { Code }\end{array}$} & \multicolumn{2}{|c|}{ Growth performance } & \multirow{2}{*}{$\frac{\text { BV }}{\text { DBH8(9) }}$} & \multirow{2}{*}{$\begin{array}{l}\text { Tree } \\
\text { Code }\end{array}$} & \multirow[t]{2}{*}{ Provenance } & \multirow{2}{*}{$\begin{array}{l}\text { Pamily } \\
\text { Code }\end{array}$} & \multicolumn{2}{|c|}{ Growth performance } & \multirow{2}{*}{$\frac{\mathrm{BV}}{\mathrm{DBH} 8(9)}$} \\
\hline & & & IIT8(9) & DBH $8(9)$ & & & & & $\operatorname{IHT}(9)$ & DBH $8(9)$ & \\
\hline 10536 & GD23 & 233 & 11.5 & 22.4 & 1.127 & 10167 & GD23 & 259 & 11 & 17.8 & 0.627 \\
\hline 11494 & $\mathrm{GD} 23$ & 259 & 18.6 & 21.8 & 0.948 & 10224 & $\mathrm{GD} 23$ & 254 & 7 & 11.4 & 0.627 \\
\hline 10215 & $\mathrm{GD} 22$ & 220 & 12.5 & 21.3 & 0.945 & 11365 & $\mathrm{GD} 22$ & 213 & 19.8 & 18.2 & 0.621 \\
\hline 10163 & $\mathrm{GI} 23$ & 244 & 12.5 & 20.7 & 0.890 & 14056 & FJI31 & 312 & 10.3 & 16 & 0.615 \\
\hline 14177 & FJ 31 & 301 & 119 & 19 & 0.888 & 11350 & $\mathrm{GD} 22$ & 226 & 16.4 & 18.1 & 0.612 \\
\hline 10251 & $\mathrm{GIJ21}$ & 205 & 10.5 & 19.8 & 0.809 & 11429 & $\mathrm{GI} 23$ & 254 & 15.2 & 18.1 & 0.612 \\
\hline 10533 & $\mathrm{GIJ22}$ & 222 & 9.5 & 189 & 0.809 & 10474 & $\mathrm{GID23}$ & 254 & 7.8 & 16.7 & 0.609 \\
\hline 10534 & $\mathrm{GD} 22$ & 213 & 10 & 18.9 & 0.809 & 13108 & GX15 & 43 & 19.4 & 18.5 & 0.603 \\
\hline 10598 & $\mathrm{GD} 22$ & 231 & 9.5 & 18.9 & 0.809 & 13109 & $\mathrm{GX} 12$ & 26 & 19 & 18.5 & 0.603 \\
\hline 10639 & $\mathrm{GD} 23$ & 247 & 10.5 & 18.9 & 0.809 & 10531 & GD23 & 264 & 9.5 & 16.6 & 0.600 \\
\hline 10085 & $\mathrm{GD} 23$ & 234 & 11.5 & 19.6 & 0.790 & 11871 & $\mathrm{GD} 22$ & 216 & 17.7 & 19.2 & 0.598 \\
\hline 14040 & F.J31 & 322 & 12.6 & 17.9 & 0.788 & 11328 & $\mathrm{GD} 23$ & 250 & 17.8 & 17.9 & 0.594 \\
\hline 10557 & $\mathrm{GD} 23$ & 252 & 9.5 & 18.6 & 0.781 & 11573 & $\mathrm{GD} 22$ & 219 & 18 & 17.9 & 0.594 \\
\hline 10498 & $\mathrm{Gl} 22$ & 226 & 9.5 & 18.2 & 0.745 & 10338 & GID2I & 208 & 10 & 16.5 & 0.590 \\
\hline 10550 & (j) 22 & 224 & 9.5 & 18.1 & 0.736 & 13908 & FJ32 & 327 & 8.2 & 15.7 & 0.588 \\
\hline 11830 & $\mathrm{GD} 23$ & 250 & 18 & 20.7 & 0.734 & 14171 & T.J31 & 308 & 9.5 & 15.7 & 0.588 \\
\hline 10615 & $\mathrm{GD} 23$ & 256 & 10.5 & 17.7 & 0.700 & 12224 & $\mathrm{GX} 17$ & $\$ 1$ & 26.4 & 21.7 & 0.585 \\
\hline 11947 & $\mathrm{GD} 21$ & 207 & 18.7 & 20.3 & 0.698 & 11576 & $\mathrm{GD} 22$ & 214 & 18 & 17.8 & 0.585 \\
\hline 10136 & $\mathrm{GD} 21$ & 201 & 10.5 & 18.5 & 0.690 & 10111 & GD21 & 204 & 10.5 & 17.3 & 0.581 \\
\hline 11907 & $\mathrm{GD} 23$ & 250 & 19.1 & 20.2 & 0.689 & 10155 & $\mathrm{GD} 22$ & 230 & 11.1 & 17.3 & 0.581 \\
\hline 14169 & FJ31 & 304 & 1.5 & 16.7 & 0.679 & 10530 & $\mathrm{GD} 22$ & 218 & 11 & 16.4 & 0.581 \\
\hline 13910 & HJ31 & 304 & 8.2 & 17.5 & 0.674 & 10186 & $\mathrm{GI} 22$ & 232 & 10 & 17.2 & 0.572 \\
\hline 10505 & $\mathrm{GI} 222$ & 212 & 8.5 & 17.4 & 0.672 & 10532 & $\mathrm{GD} 21$ & 201 & 9.5 & 16.3 & 0.572 \\
\hline 10483 & $\mathrm{GD} 23$ & 234 & 8.6 & 17.3 & 0.663 & 10607 & GD23 & 259 & 8.9 & 16.3 & 0.572 \\
\hline 10523 & $\mathrm{Gil} 22$ & 219 & 7.9 & 17.3 & 0,663 & 14166 & $|+J 3|$ & 323 & 9.6 & 15.5 & 0.569 \\
\hline 14007 & FJ31 & 314 & 11.5 & 16.4 & 0.651 & 11108 & $\mathrm{GD} 23$ & 254 & 18.5 & 17 & 0.561 \\
\hline 10193 & $\mathrm{CD} 23$ & 235 & 11 & 18 & 0.645 & 13900 & FJ33 & 335 & 8.6 & 15.4 & 0.560 \\
\hline 14149 & F.J31 & 320 & 12 & 16.3 & 0.642 & 11575 & $\mathrm{GD} 22$ & 222 & 19.6 & 17.5 & 0.557 \\
\hline 14180 & FJ31 & 304 & 9.5 & 16.2 & 0.633 & 11855 & GD22 & 229 & 19.1 & 18.7 & 0.552 \\
\hline 14181 & FJ33 & 338 & 9 & 16.2 & 0.633 & 11860 & $\mathrm{GD} 22$ & 219 & 15.4 & 18.7 & 0.552 \\
\hline
\end{tabular}

${ }^{a}$ Measurement age are varied among different province population. 
a similar genetic gain $(\mathrm{E}=74.3 \%$ and $100 \%)$ as selection for $\mathrm{DBH}$ at age 9 years in C. hystrix.

Moderate to high heritability for $\mathrm{HT}, \mathrm{DBH}$, and $\mathrm{CW}(0.31,0.24$, and 0.22 , respectively) as indicated by this study suggests that improvements in growth and form traits can be accomplished via phenotypic selection. The high significant positive genetic correlations for these growth and form traits suggest that selection for one trait would bring highly correlated genetic performance at another trait. The breeding values predicted in the study can be used to select families and individuals for immediate deployment using seed orchard or for further breeding purpose. In the future, fullsib progeny trials should be established to control pedigree while move breeding population into more advanced generation.

\section{Conclusions}

Our conclusions based on genetic parameters and selection of breeding values for growth and form traits in C. hystrix by analyzing each province population planted in China are summarized as:

(1) Provenance effects were not significant for growth and form traits with each meta population delineated by province and family within provenaces has a significant variance component for each province population.

(2) Significant heritabilities for most traits of HT, DBH, GD, and CW were observed for each province population and combined three provinces, Heritability estimates for $\mathrm{H}$ and DBH decreased with increasing age for Guangdong province population and combined three provinces.

(3) Significant genetic correlations for age-age and trait-trait correlations were observed and the correlations were high for all traits at all ages, indicating that genetic performance will be highly correlated among traits and early selection was effective.

(4) In total, 22 families from three provinces and 60 individuals for combined three provinces were selected based on breeding values to maximize breeding progress.

\section{Acknowledgements}

This study was financially supported by Science and Technology Planning Project of
Guangdong Province, China (2014B020202002). The authors thank Dr. HARRY WU and KHONGSAK PINYOPUSARERK of CSIRO for helpful comments on the manuscript.

\section{References}

CoRnelius, J. (1994): Heritabilities and additive genetic coefficients of variation in forest trees. Can J For. Res. 24: 372-379.

Denis, M. and J. M. Bouvet (2013): Efficiency of genomic select ion with models including dominance effect in the context of Eucalyptus breeding. Tree Genet. Genomes. 9: 32-51.

ERICSSON, T. and A. FRIES (2004): Genetic analysis of fibre size in a full-sib Pinus sylvestris L. progeny test. Scand. J For Res 19: 7-14.

FALCONER, D. S. and T. F. C. MACKAY (1996): An introduction to quantitative genetics, $4^{\text {th }}$ edn. Longman, Essex.

Freeman, J. S., C. M. P. Marques, V. Carocha, N. M. G. Borralho, B. M. Potts and R. E. VAILlANCOURT (2007): Origins and diversity of the Portuguese Landrace of Eucalyptus globulus. Ann For Sci. 64: 639-647.

FriEs, A. (2012): Genetic parameters, genetic gain and correlated responses in growth, fibre dimensions and wood density in a Scots pine breeding population. Annals of Forest Science 69: 783-794.

Fries, A. and T. ERICSSON (2006): Estimating genetic parameters for wood density of Scots pine (Pinus sylvestris L.). Silvae Genet 55: 84-92.

Fries, A. and T. ERICSSON (2009): Genetic parameters for earlywood and latewood densities and development with increasing age in Scots pine. Ann For Sci 66: 404.

Gapare, W. J., B. S. Baltunis, M. Ivković and H. X. WU (2009): Genetic correlations among juvenile wood quality and growth traits and optimal selection strategy in Pinus radiata D. Don. Ann. For. Sci. 66, 606-614.

Gilmour, A. R., B. R. Cullis, S. J. Welham, B. J. Gogel and R. Thompson (2009): An effcient computing strategy for prediction in mixed linear models. Comput. Stat Data An. 44, 571-586.

Greaves, B. L., N. M. G. Borralho and C. A. RaYMOND (1997): Breeding objective for plantation eucalypts grown for production of kraft pulp. For. Sci. 43: 465-472.

Gwaze, D. P., F. E. Bridgwater, T. D. Byram and W. J. LowE (2001): Genetic parameters estimates for growth and wood density in loblolly pine (Pinus taeda L.). For. Gen. 8: 47-55.

Gwaze, D. P., F. E. Bridgwater, T. D. Byram, W. J. Lowe (2001): Genetic parameters estimates for growth and wood density in loblolly pine (Pinus taeda L.). For. Gen. 8: 47-55.

HaRdner, C. M., I. S. E. BAlly and C. L. Wright (2012): Prediction of breeding values for average 
fruit weight in mango using a multivariate individual mixed model. Euphytica. 186: 463-477.

Henderson, C. R. (1975): Use of all relatives in intraherd prediction of breeding values and producing abilities [J]. Jounal of Dairy Science. 58(12): 1910-1916.

Huang, Z., H. Hao, S. Pang, Y. Peng and Y. CaO (2012): A study on the seedling growth rhythm of Castanopsis hystrix among provenance in Chinese. Forestry science and technology. 26(3): 24-28.

IsIK, F., B. LI, B. GoldFARB and S. McKeAnd (2008): Prediction of wood density breeding values of Pinus taeda elite parents from unbalanced data: A method $f$ or adjustment of site and age effects using common checklots. Ann. For. Sci. 65: 406-418.

IwATA, H., T. HAYASHI and Y. TSUMURA (2011): Prospects for genomic select ion in conifer breeding: a simulation study of Cryptomeria japonica. Tree Genet. Genomes. 7: 747-758.

JAYAWICKRAMA, K. J. S. (2001): Genetic parameter estimates for radiata pine in New Zealand and New South Wales: a synthesis of results. Silvae Genet. 50, 45-53.

LI, L. and H. X. WU (2005): Efficiency of early selection for rotation-aged growth and wood density traits in Pinus radiata. Can. J. For. Res. 35, 2019-2029.

Lopez, G. A., B. M. Potts, G. W. Dutkowski, L. A. ApiolazA and P. E. GELID (2002): Genetic variation and inter-trait correlations in Eucalyptus globules base population trials in Argentina. For Genet. 9: 217-231.

Matheson, A. C., W. G. Gapare, J. Ilic and H. X. Wu (2008): Inheritance and genetic gain in wood stiffness in radiata pine measured acoustically in standing young trees. Silvae Genet. 57, 56-64.

Potts, B. M., R. E. Vaillancourt, G. J. Jordan, G. W. Dutkowski, J. Costa e Silva, G. E. McKinnon, D. A. Steane, P. W. Volker, G. A. Lopez, L. A. Apiolaza, Y. Li, C. M. P. Marques and N. M. G. BorRALHO (2004): Exploration of the Eucalyptus globulus gene pool. In: Borralho, N. M. G., Pereira, J. S., Marques, C. M. P., Coutinho, J., Madeira, M., Tomé, M. (eds Eucalyptus in a changing world. Proceedings IUFRO Conference, Aveiro, Portugal, 11-15 October 2004. RAIZ (Instituto Investigação de Floresta e Papel), Portugal, 46-61.

White, T. L., A. W. Thomas and D. B. Neale (2007): Forest genetics. CAB International, Wallingford UK.

Wu, H. X., K. G. Eldridge, A. C. Matheson, M. P. Powell and T. A. MCRAe (2007): Achievement in forest tree improvement in Australia and New Zealand 8. Successful introduction and breeding of radiata pine to Australia. Aust. For. 70, 215-225.

Wu, H. X., K. G. Eldridge, A. C. Matheson, M. P. Powell and T. A. MCRAe (2007): Achievement in forest tree improvement in Australia and New Zealand 8. Successful introduction and breeding of radiata pine to Australia. Aust. For. 70, 215-225.

Wu, H. X., M. Ivković, W. J. Gapare, A. C. Matheson, B. S. Baltunis, M. B. Powell and T. A. McRae (2008): Breeding for wood quality and profit in radiata pine: a review of genetic parameters and implication for breeding and deployment. N. Z. J. For. Sci. 38: 56-87.

Wu, H. X. and A. C. MAtheson (2002): Quantitative genetics of growth and form traits in radiata pine. CSIRO Forestry and Forests Technical Report 138 and Southern Tree Breeding Association Technical Report TR02-01, CSIRO, Canberra.

Xie, C. Y., M. R. CARLson and J. C. Murphy (2007): Predicting individual breeding values and making forward selections from open-pollinated progeny test trials for seed orchard establishment of interior Lodgepole Pine (Pinus contorta ssp. latifolia) in British Columbia. New Forests. 33: 125-138.

Zhang, F., D. Liang, Z. Chen, Y. Huang, W. Pan, J. Han, S. Yang, M. Wang, Y. LiU, Z. Liang, Z. CHEN and X. ZHU (2005): The variation regularity on seedling growth of Castanopsis hystrix in different population and families in chinese. Guangdong Academy of Forestry. 22(4): 7-12.

ZHU, J., Y. JiAnG, R. LIANG and L. LU (2005): A preliminary report on tree planting test of provenances and families of Castanopsis hystrix in Guangxi in Chinese. Journal of west china forestry science. 34(4): 5-10. 